\title{
Paradigm Lost,
}

\section{Paradigm Found}

\section{The Black Sea-Black Shale Connection as Viewed from the Anoxic Basin Margin}

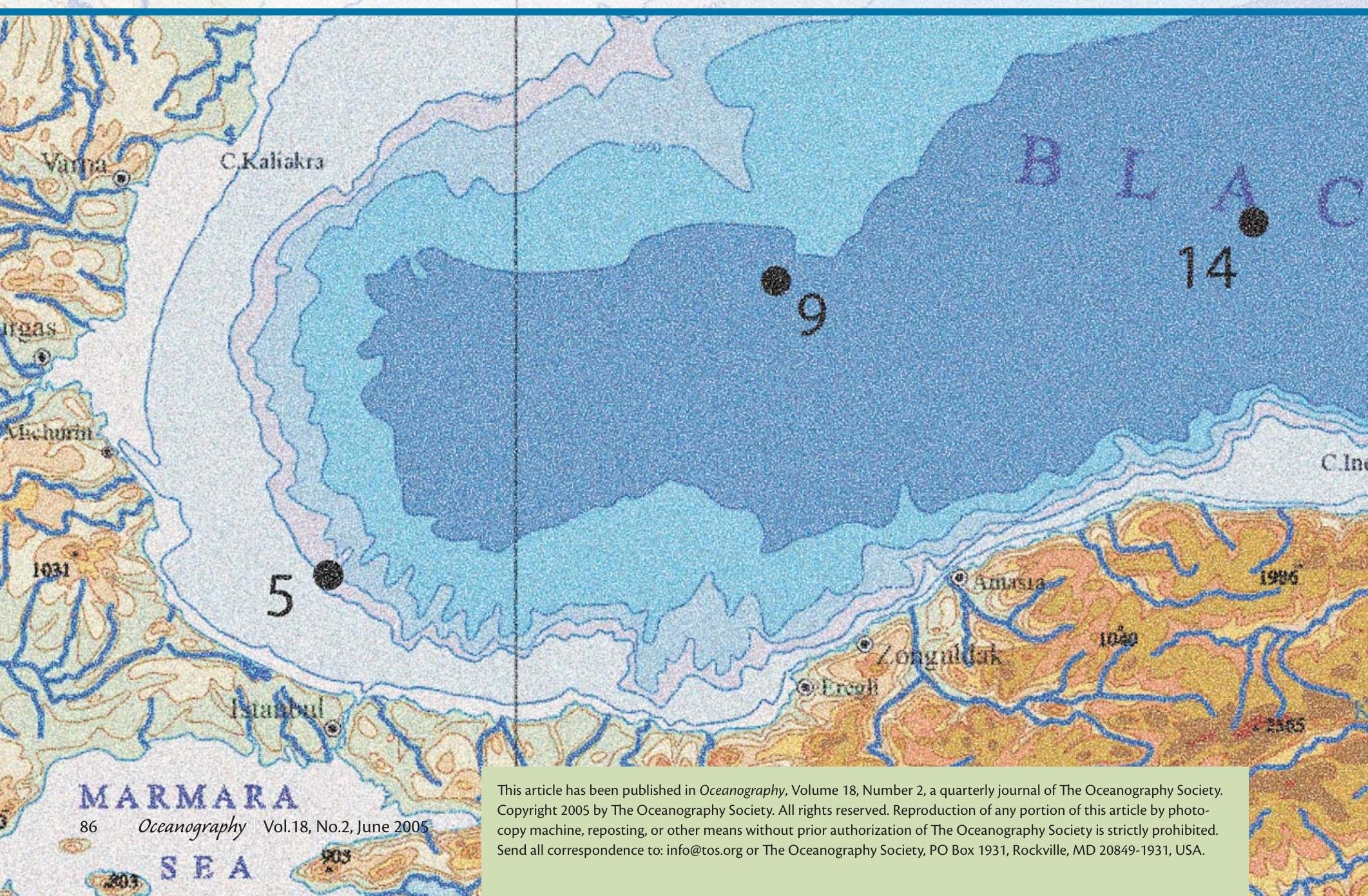


rite formation and thus euxinic (anoxic and sulfidic) bottom-water conditions. Iron-based proxies have been invaluable in the interpretation of ancient black shales (Raiswell et al., 1988; Werne et al., 2002; Shen et al., 2003). Water-column (syngenetic) iron sulfide formation is also expressed in the uniform and comparatively small sizes observed for pyrite framboids that form in suspension and settle to the bottom as part of Unit 1, in contrast to the larger and more scattered framboid diameters observed forming during diagenesis beneath oxic bottom waters (Wilkin et al., 1997; Wilkin and Arthur, 2001). The utility of this proxy has also been readily extrapolated to studies of ancient shales (Wignall and Newton, 1998), as have the uniform and strongly ${ }^{34} \mathrm{~S}$-depleted $\mathrm{S}$ isotope values that characterize pyrite formation within large water-column reservoirs (Shen et al., 2003; Sageman and Lyons, 2004). In euxinic settings, diagenetic overprints are often minimized by Fe limitations that preclude substantial additional $\mathrm{Fe}$ sulfide formation within the sediments (Lyons and Berner, 1992; Lyons, 1997; Wilkin and Arthur, 2001). On a cautionary note, light and uniform $\delta^{34} \mathrm{~S}\left({ }^{34} \mathrm{~S} /{ }^{32} \mathrm{~S}\right)$ values can occur in pyrite forming diagenetically beneath oxic waters (Wijsman et al., 2001a).

Organic geochemists have had similar success in the Black Sea, including their

Timothy W. Lyons (timothy.lyons@ucr. edu) is Professor of Biogeochemistry, Department of Earth Sciences, University of California, Riverside, CA, USA. Michaele Kashgarian is Research Scientist, Center for Accelerator Mass Spectrometry L-39, Lawrence Livermore National Laboratory, Livermore, CA, USA. use of biomarkers that point to photiczone euxinia by specifically delineating anoxygenic primary production by photoanaerobes in the presence of water-column dissolved sulfide (Sinninghe Damsté et al., 1993). More recently, Arnold et al. (2004) emphasized that the Black Sea, because of its ubiquity of dissolved sulfide in the water column and sediments, can capture the bulk Mo isotope ratio found in seawater throughout the world ocean. This capture of the seawater signal suggests that the analysis of euxinic black shales spanning the geologic record may provide an estimate of the relative proportions of oxic, anoxic, and suboxic deposition in the ancient ocean (Arnold et al., 2004).

In the modern Black Sea, the validity of each geochemical proxy for euxinia is most clear within Unit 1, the coccolith-rich, microlaminated sediments that typify uppermost Holocene, nonturbiditic deposition in the deep basin (ca. $2000 \mathrm{~m}$ ). Unit 1 is described in detail elsewhere (Ross et al., 1970; Lyons, 1991; Lyons and Berner, 1992; Arthur et al., 1994; Arthur and Dean, 1998). On the basin margin at water depths of only about $200 \mathrm{~m}$, but beneath a persistently sulfidic water column, a very different story emerges. Here, the physical and geochemical properties of the black, soupy, fine-grained siliciclastic-dominated sediments are strongly impacted by sedimentation rates that approach and exceed $0.7 \mathrm{~cm} / \mathrm{y}$.

Millions of years from now, when this euxinic basin-margin facies enters the geologic record, future scientists will be steered toward a euxinic interpretation by the persistence of undisturbed microlaminae marking the absence of a benthic macrofauna. However, the geochem- istry — specifically the deviations from typical euxinic properties - will tell a more nuanced story. This paper explores a unique, but perhaps not unusual, facies along the Black Sea margin where the euxinic paradigm fails. Analogous settings likely abound in the ancient record and are known elsewhere in the modern world, such as the rapidly accumulating sediments of anoxic fjords. Nevertheless, if locked into only traditional views of euxinic deposition and associated geochemistry, paleoenvironmental interpretations of this facies will almost certainly miss the mark, yielding instead assertions of weakly oxic, intermittently anoxic, or anoxic but nonsulfidic conditions. Such weakly and ephemerally reducing environments certainly do exist now and have in the past (Sageman et al., 2003). However, a more sophisticated model for euxinic sediments, such as one that spans gradients in sedimentation rate, carbon source, and sediment type, will shed light on the range of proxy data that are possible beneath a persistently sulfidic water column. Rather than adding complexity, this variance broadens the spectrum of paleoenvironmental information that can be extracted from very old sedimentary rocks. It is the authors' hope that this synthesis of new and previously published results from the Black Sea will help in building a template for these refined interpretations.

\section{MATERIALS AND METHODS}

This study focuses on only two sites sampled during Leg 4 of the 1988 cruise of the R/V Knorr: Stations 5 and 15 at water depths of 233 and 198 meters, respectively (Figure 1) (Lyons, 1991). All of the data reported from a particular station were generated from a single core col- 


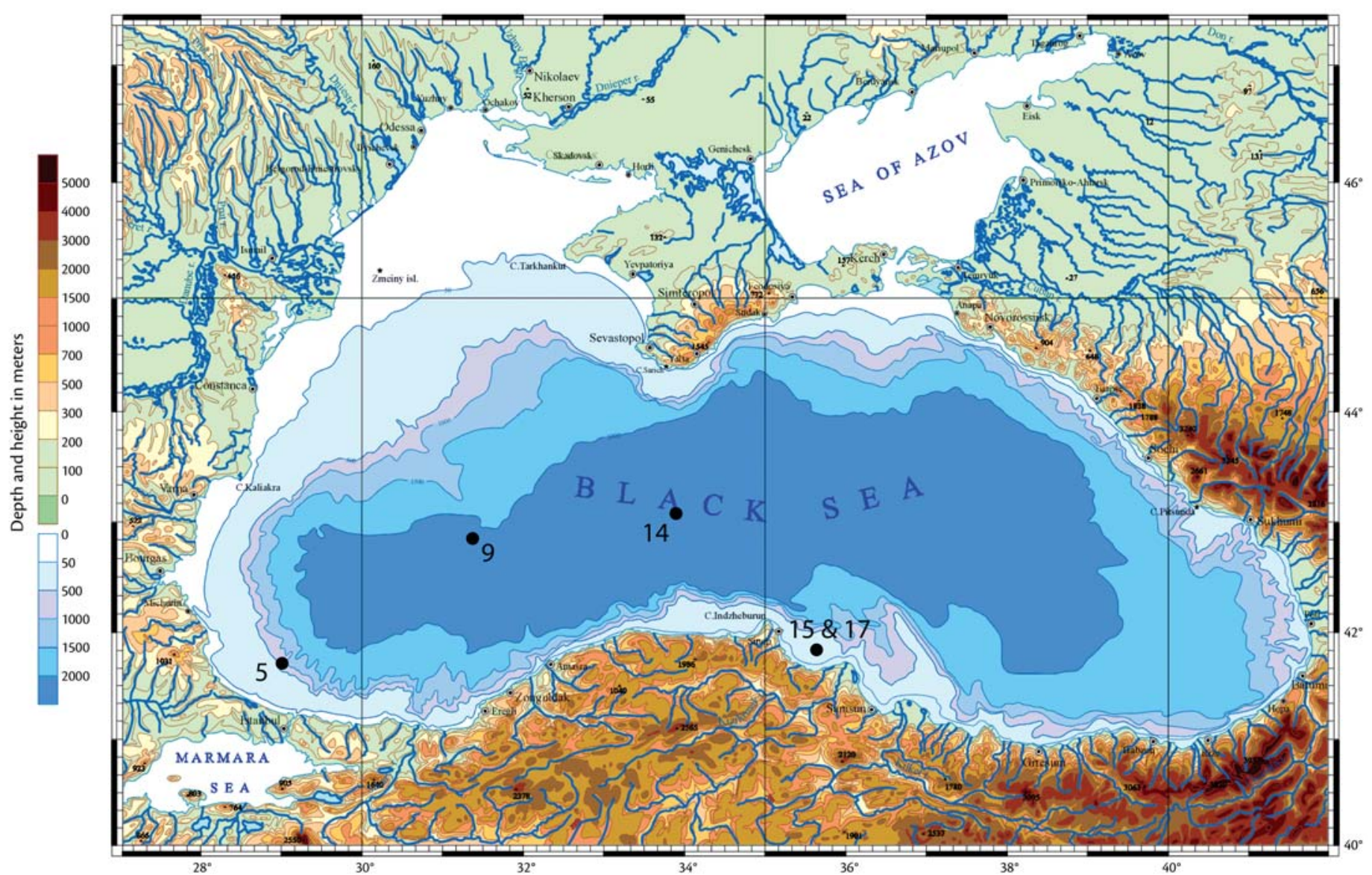

Figure 1. Map showing locations of Stations 5, 9, 14, 15, and 17 of the 1988 R/V Knorr Black Sea expedition (after S. Stanichny, Marine Hydrophysical Institute, Ukraine, unpublished). Location details and sedimentological properties at each site are provided in Lyons (1991). Station 15, a rapidly accumulating euxinic site on the upper slope, is emphasized in the present study.

lected at the site in question. Both sites are the euxinic end members of coring transects spanning the impingement of the chemocline with the basin margin. Although below the sulfide interface, Stations 5 and 15 are small lateral and vertical distances from oxygen-containing bottom waters (Lyons, 1991). How broadly the two upper-slope stations represent sediments rimming the Black Sea margin remains a topic of debate. For example, Wijsman et al. (2001a), based on work along the northwest margin of the Black Sea, noted the highly variable nature of the sulfur properties at shelf and upper slope sites. Nevertheless, our results reveal strong similarities at two widely spaced localities along the Turkish coast, and the properties of these sediments are expressed in muddy turbidites found deep in the basin. The suggestion, therefore, is that the muds at Stations 5 and 15 are not rare-at least within a specific belt of deposition along the Black Sea margin. Throughout this article, the sediment properties at these two sites are contrasted with those of the proximal oxic shelf and the deep central euxinic basin.

The sedimentological and geochemi- cal properties of muds at Stations 5 and 15 and adjacent localities have been described in detail elsewhere (Cowie and Hedges, 1991; Lyons, 1991, 1997; Lyons et al., 1993; Anderson et al., 1994; Hurtgen et al., 1999). Briefly, the muds at 5 and 15 are water-rich and soupy with alternating, millimeter- to centimeter-scale dark gray and jet black color bands. The pigments reflect the anomalous concentrations of iron monosulfide phases that persist over depths of tens of centimeters; a finer-scale lamination is revealed under $\mathrm{x}$-radiographic analysis (Anderson et al., 1994). Despite evidence for vertical 
excursions of the chemocline (Murray et al., 1989; Lyons et al., 1993; Anderson et al., 1994), the undisturbed nature of the microlaminae suggests persistence of at least anoxic deposition over the ca. $50 \mathrm{~cm}$ recovered at each site. Nearby shallower sediments show signs of weakto-pervasive burrowing, confirming the proximity of the chemocline (Lyons, 1991; Anderson et al., 1994).

Previously published methods and results, highlighted here but described in detail in Lyons and Berner (1992), Lyons (1997), and Hurtgen et al. (1999), include organic and inorganic carbon analysis using a LECO carbon analyzer before and after sample ashing. We quantified iron monosulfide ("FeS") sulfur through extraction at room temperature using $6 \mathrm{~N} \mathrm{HCl}$ and 15 percent $\mathrm{SnCl}_{2}$. Because of their solubility in $\mathrm{HCl}$, these monosulfide phases are also collectively known as acid-volatile sulfide or AVS. We isolated pyrite $\mathrm{S}$ from the $\mathrm{HCl}$ residue using the chromium reduction method. We determined concentrations of pyrite-S and AVS-S by titration of the $\mathrm{ZnS}$ precipitates and measured $\mathrm{S}$ isotope ratios through on-line combustion of $\mathrm{Ag}_{2} \mathrm{~S}$ precipitates to $\mathrm{SO}_{2}$ for mass spectrometry. We determined total Fe, $\mathrm{Mo}$, and $\mathrm{Al}$ by $\mathrm{HF} / \mathrm{HNO}_{3} / \mathrm{HClO}_{4}$ digestion, with quantification by inductively coupled plasma optical emission spectrometry. Degree-of-sulfidation (DOS) is defined as:

DOS $=\frac{\text { AVS-Fe }+ \text { pyrite-Fe }}{\text { AVS-Fe }+ \text { pyrite-Fe }+ \text { extractable-Fe }}$

where "extractable Fe" is the fraction of total solid-phase Fe that is readily solubilized during a boiling $12 \mathrm{~N} \mathrm{HCl}$ distillation. DOS is directly analogous to DOP
(Raiswell et al., 1988), which is the ratio of (pyrite-Fe)-to-(pyrite-Fe + extractable-Fe), but is used for sediments rich in AVS. In both cases, the iron sulfide Fe fractions are calculated from measured values of AVS-S and pyrite-S, assuming $\mathrm{FeS}$ and $\mathrm{FeS}_{2}$ stoichiometries, respectively. We measured dissolved sulfide $\left(\mathrm{KH}_{2} \mathrm{~S}\right)$ spectrophotometrically using the methylene blue method. Prior to sulfide analysis, we isolated pore waters by centrifugation and fixed the dissolved sulfide as $\mathrm{ZnS}$ under an $\mathrm{N}_{2}$ atmosphere.

We generated new radiocarbon data for total organic and inorganic carbon using accelerator mass spectrometry at Lawrence Livermore National Laboratory. For organic carbon analysis, we treated the samples with $1 \mathrm{~N} \mathrm{HCl}$ washes to remove carbonate phases, rinsed with distilled water, and dried under vacuum. We then combusted the samples in sealed quartz tubes with $\mathrm{CuO}$ and $\mathrm{Ag}$ at 900 degrees $\mathrm{C}$ to produce $\mathrm{CO}_{2}$ that was reduced to graphite grown on cobalt powder. We prepared carbonate samples by acidification, yielding $\mathrm{CO}_{2}$ for graphitization.

\section{RESULTS AND DISCUSSION Organic Carbon}

Organic carbon $\left(\mathrm{C}_{\text {org }}\right)$ concentrations at Stations 5 and 15 average 2.5 and 1.6 wt.\%, respectively (Figure 2), compared with a mean of $5.3 \mathrm{wt} \%$ for Unit 1 sediments of the central basin (Lyons, 1997; Lyons and Berner, 1992). Cowie and Hedges (1991) argued for a dominantly marine organic reservoir at Station 15, based on ratios of $\mathrm{C}_{\text {org }}$-to-total $\mathrm{N}$, and a common (planktonic) source at Station 15 and the proximal oxic and transitional sites. Diagenesis, as expressed in the $\mathrm{C}_{\text {org }}$ and total $\mathrm{N}$ data, was spread over a greater depth at Station 15 relative to the oxic and suboxic sites, presumably reflecting the protracted organic remineralization under conditions of anoxic and rapid sediment accumulation. Comparatively high rates of subsurface anaerobic respiration at the euxinic margin sites are reflected in elevated dissolved sulfide $\left(\Sigma \mathrm{H}_{2} \mathrm{~S}\right)$ concentrations and depleted sulfate levels relative to the shallower oxic and transitional stations - and even relative to the Unit 1 sediments at ca. $2000 \mathrm{~m}$ water depth when compared to Station 5. Mean values for $\Sigma \mathrm{H}_{2} \mathrm{~S}$ are 1069 and $80 \mu \mathrm{M}$ at Stations 5 and 15, respectively, compared to $462 \mu \mathrm{M}$ in the pore fluids of Unit 1 and values below detection $(3 \mu \mathrm{M})$ in the transitional and oxic sediments (Lyons and Berner, 1992; Lyons et al., 1993). Consistent with low sulfide production in the oxic and transitional stations, concentrations of Fe-sulfide $\mathrm{S}$ are low_ranging from less than $0.1 \mathrm{wt} \% \%$ to a few tenths of a weight percent. Exceptions reflect earlier episodes of euxinia on the now oxic shelf (Lyons et al., 1993).

The sediments of the central basin provide a contrast. Despite pyrite $S$ concentrations that average $1.3 \mathrm{wt} . \%$ in Unit 1 (Lyons and Berner, 1992), most of this pyrite formed in the water column. Also, Unit 1 sediments are not, overall, sites of strongly enhanced sulfate reduction (Albert et al., 1995). The comparatively low reactivity of Unit 1 organic matter, with the exception of the surface layer, is corroborated by measured and modeled rates of sulfate reduction and by the high subsurface concentrations of sulfate relative to Stations 5 and 15 (Lyons and Berner, 1992; Albert et al., 1995; Jørgensen et al., 2001). These observations are consistent with the notion that subsurface organic reactivity is positively correlated with the rate of bulk sedimentation 
(Toth and Lerman, 1977). The decidedly nonsteady-state nature of the $\mathrm{\Sigma H}_{2} \mathrm{~S}$ profile at Station 15 is noteworthy and will be discussed further (Figure 3).

\section{Sulfur}

The most striking observation in the sulfur chemistry of the euxinic basin margin is the abundance of AVS that persists to depths of at least $50 \mathrm{~cm}$, the base of the cores at Stations 5 and 15 (Figure 4). Under most depositional conditions, the conversion of AVS ("FeS") to pyrite occurs predominantly in the upper sev- eral centimeters of burial or in the water column. However, protracted transformation of iron mono- to disulfide is observed in modern marine sediments and commonly characterizes sites of very rapid accumulation, both oxic and anoxic, where the iron monosulfide pyrite precursors are rapidly removed from intermediate S phases such as polysulfide ions (Hurtgen et al., 1999). These sulfur intermediates are typically credited with the conversion of "FeS" to pyrite (Schoonen, 2004). Under such conditions, the delayed transformation may instead re- cord the direct reaction between "FeS" and $\mathrm{H}_{2} \mathrm{~S}$ (Rickard and Luther, 1997; Hurtgen et al., 1999; Schoonen, 2004), although this mechanism is controversial.

Rapid accumulation also favors burial of reactive Fe and organic matter that would otherwise be consumed at the sediment-water interface. As a result, AVS formation may also be delayed. At Stations 5 and 15, however, DOS profiles do not show simple increases as would be expected with additional AVS formation at depth. Instead, the DOS profile at Station 15 (Figure 5) shows a nonsys-

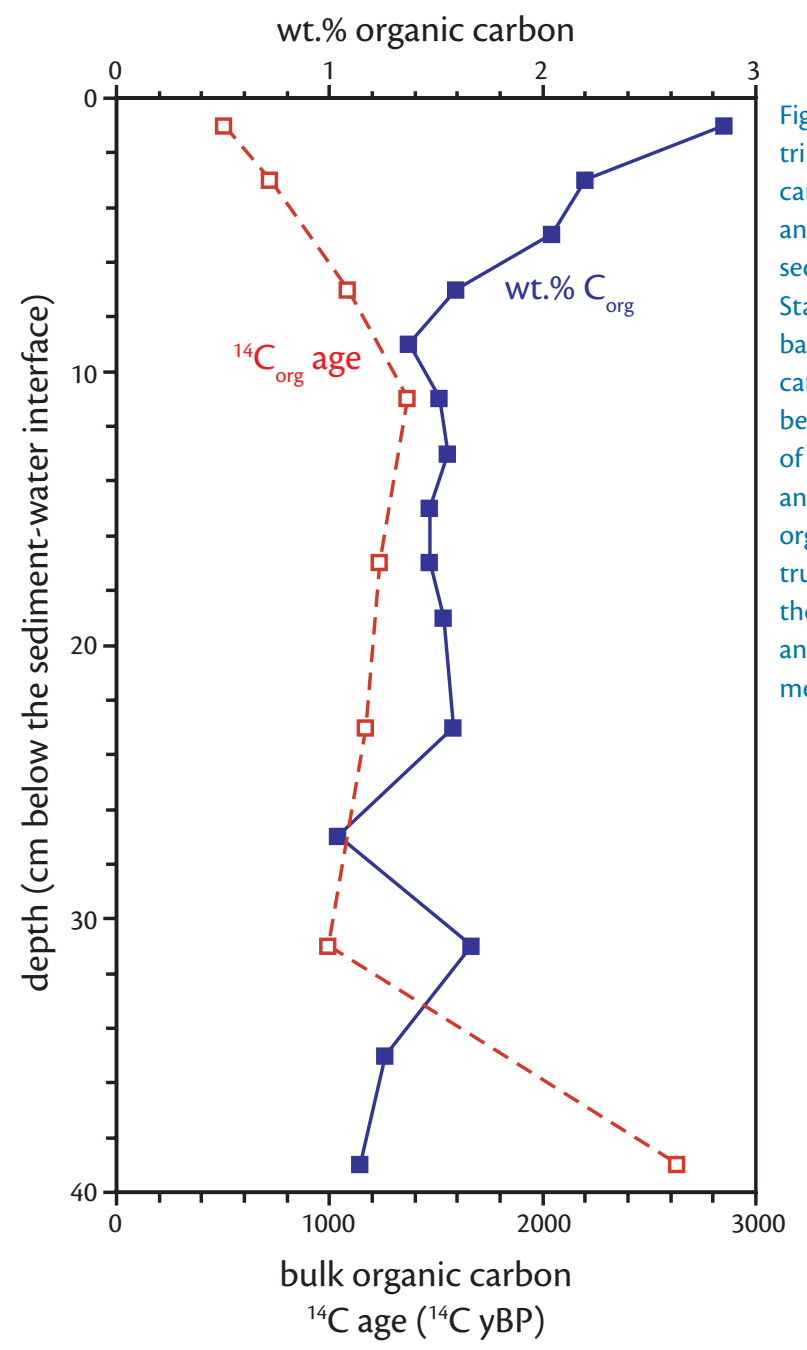

Figure 2. Downcore distributions of organic carbon concentrations and bulk ${ }^{14} \mathrm{C}$ ages for sediments collected at Station 15 on the euxinic basin margin. The radiocarbon profile appears to be a stronger reflection of sediment reworking and incorporation of old organic matter than the true depositional age of the soupy, black mud and the associated sedimentation rate.

pore water total dissolved sulfide $(\mu M)$

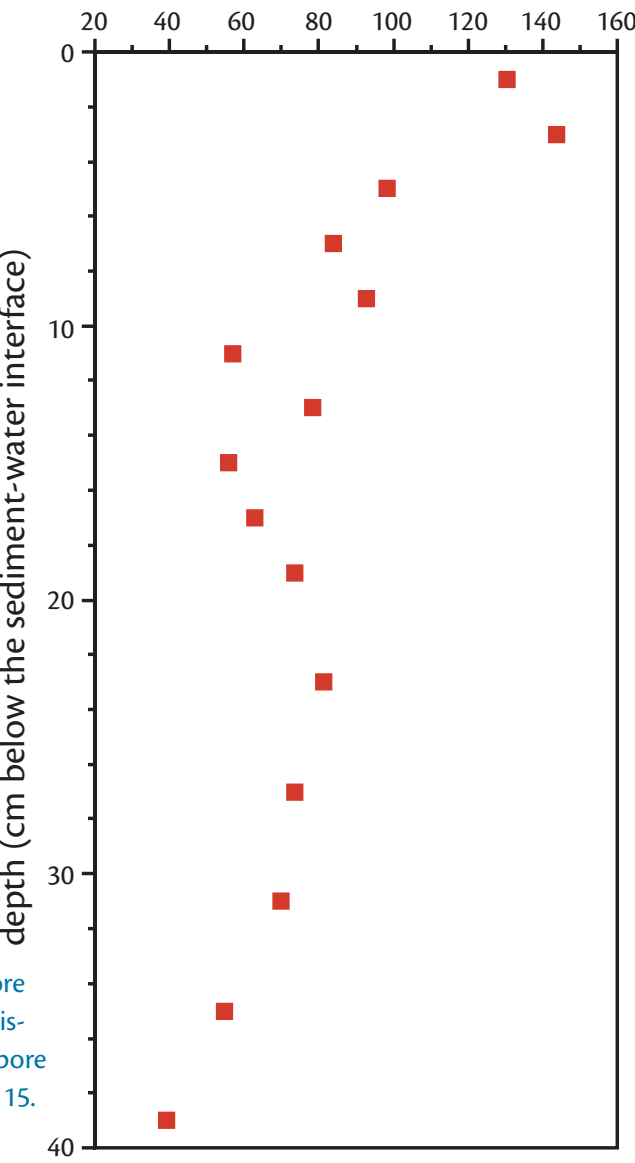

Figure 3. Downcore profile for total dissolved sulfide in pore waters at Station 15. 
tematic decrease down core. DOS at Station 5 also ranges between 0.3 and 0.5 , with the suggestion of a noisy and subtle downcore increase.

Sulfur isotope data for AVS and pyrite at Station 15 are summarized in Table 1 relative to those for the deep basin euxinic stations. Although much of the AVS formation appears to be early (Figure 4), the AVS-to-pyrite transformation persists at depth under more restricted sulfate-sulfide reservoir conditions. The collective contributions of subsurface iron sulfide formation result in $\delta^{34} \mathrm{~S}$ values for mono- and disulfide at Station 15 that are on average roughly $11 \%$ o heavier than the pyrite in Unit 1. In contrast to the diagenetic contributions on the basin margin, the majority of Unit 1 pyrite formation occurs in the sulfidic water column (Calvert et al., 1996; Lyons, 1997; Wilkin et al., 1997; Wilkin and Arthur, 2001), and subsurface Fe limitations preclude substantial iron sulfide formation during diagenesis. Details of these relationships are provided in Lyons (1997).

\section{Fe and Mo}

The Fe and Mo properties of Stations 5 and 15 contrast sharply with those of Unit 1 and are more similar to those of the oxic shelf (Table 2). In Unit 1, syngenetic pyrite formation results in pronounced enrichments in reactive $\mathrm{Fe}$ that manifest in elevated ratios of highly reactive-to-total $\mathrm{Fe}$ and total $\mathrm{Fe}$-to- $\mathrm{Al}$, as well as high DOP (DOS) values. Much has been written and debated about the source of this "extra" scavenged Fe and the mechanisms of transport and enrichment (Canfield et al., 1996; Raiswell and Canfield, 1998; Lyons, 1997; Wijsman et al., 2001b; Lyons et al., 2003; Anderson and Raiswell, 2004), but the empirical relationships are undeniable. Absent this Fe enrichment, prolonged exposure of typical detrital Fe to high concentrations of dissolved sulfide yield DOP values of

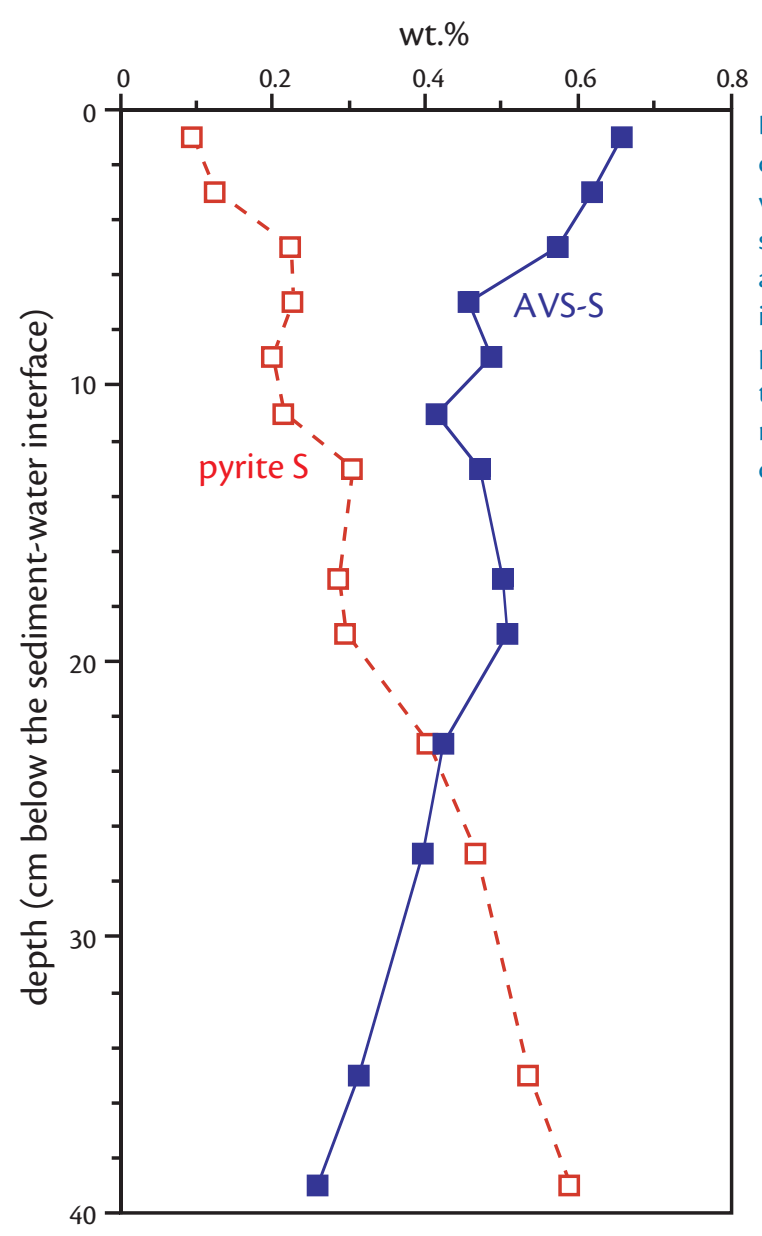

Figure 4. Downcore distributions for acidvolatile sulfide ("FeS") sulfur and pyrite sulfur at Station 15 showing progressive but protracted diagenetic transformation of iron monosulfide to iron disulfide.

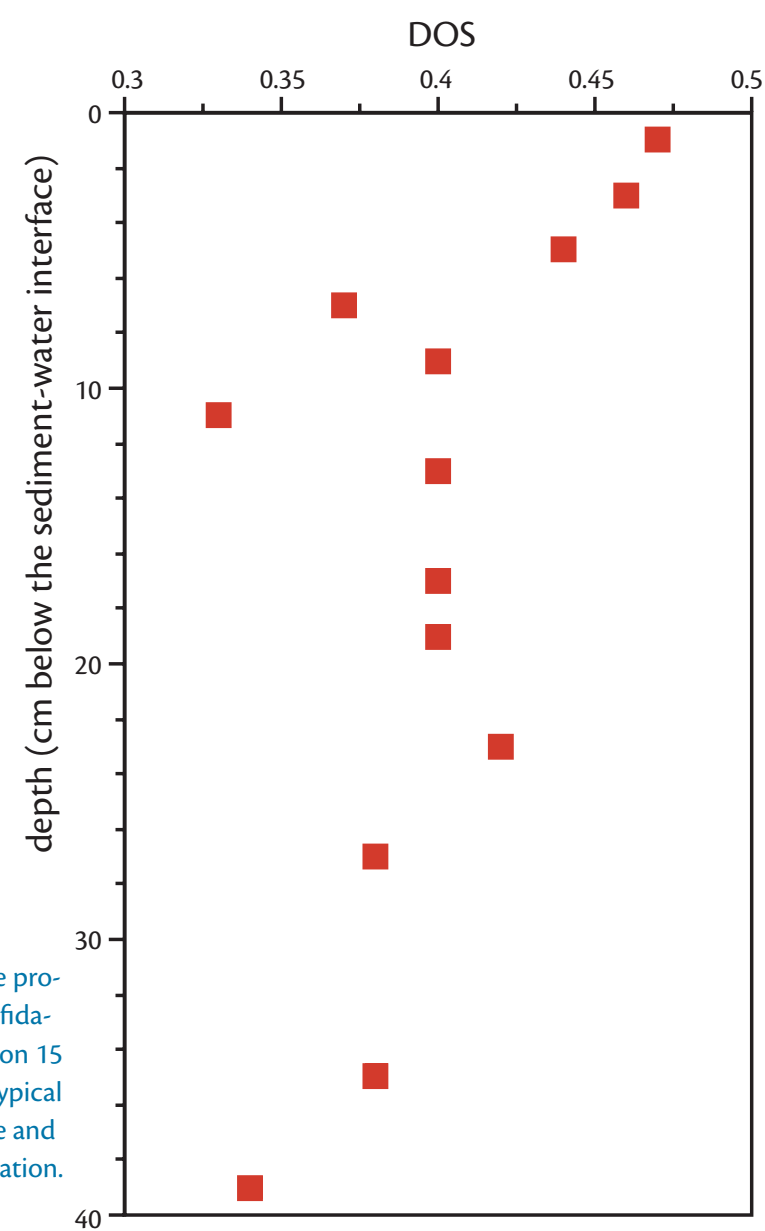

Figure 5. Downcore profile of degree of sulfidation (DOS) at Station 15 highlighting the atypical downcore decrease and nonsystematic variation. 
only intermediate ranges - which result from the consumption of total highly reactive Fe but the persistence of an appreciable unsulfidized portion of the "extractable Fe" pool. In short, the $\mathrm{HCl}$ extraction overestimates the amount of sulfide-reactive Fe in the system by removing silicate phases that are unreactive even on very long time scales (Raiswell and Canfield, 1998; Lyons et al., 2003). The same intermediate values are observed at Stations 5 and 15 because of high and persistent sulfide exposure in the sediment and water column. By this model, the scavenged reactive $\mathrm{Fe}$ component, which is required to elevate DOP (DOS) to the high values typical of euxinic settings, would be swamped by very high detrital Fe inputs. Therefore, intermediate DOP values generally reflect either organic- and sulfide-rich pore water environments beneath oxic bottom waters or euxinic conditions of rapid detrital sediment accumulation. Consistent with this assertion, Sageman and Lyons (2004) showed a general inverse relationship between DOP (DOS) in euxinic sediments and the rate of siliciclastic accumulation. Variability in DOS at Station 15 (Figure 5) within a window of intermediate values from roughly 0.3 to 0.5 appears to be linked to the amount and reactivity of organic matter in the sediments (see discussions below).

An analogous argument applies to molybdenum. Mo enrichment in black shales and modern euxinic sediments is attributed to high levels of dissolved sulfide, which facilitate a transformation from dominantly molybdate to highly particle reactive thiomolybdate ions (Helz et al., 1996). The scavenging of Mo is driven largely by organic matter, although the extent to which

Table 1. Mean values for $\delta^{34} \mathrm{~S}$ (vs. CDT) of sedimentary sulfides (pyrite, unless otherwise specified)

\begin{tabular}{|c|c|c|c|c|}
\cline { 2 - 5 } \multicolumn{1}{c|}{} & \multicolumn{2}{c|}{ euxinic, basin margin } & \multicolumn{2}{c|}{ euxinic, central basin } \\
\cline { 2 - 5 } \multicolumn{1}{c|}{ Station 15} & Station 9 & Station 14 \\
\hline \multirow{3}{*}{$\delta^{34} S(\%)$} & AVS & pyrite & $-37.3 \pm 0.7$ & $-37.0 \pm 1.1$ \\
& $-25.0 \pm 1.5$ & $-27.6 \pm 1.1$ & $( \pm 1 \sigma, \mathrm{n}=11)$ & $( \pm 1 \sigma, \mathrm{n}=7)$ \\
\hline
\end{tabular}

Data from Lyons (1997).

Table 2. Mean values for DOP (DOS), Fe/Al, and Mo/Al.

\begin{tabular}{|c|c|c|c|c|c|}
\cline { 2 - 6 } \multicolumn{1}{c|}{} & oxic, shelf & \multicolumn{2}{c|}{ euxinic, basin margin } & \multicolumn{2}{c|}{ euxinic, central basin } \\
\cline { 2 - 6 } \multicolumn{1}{c|}{} & Station 17 & Station 5 & Station 15 & Station 9 & Station 14 \\
\hline $\begin{array}{c}\text { DOP } \\
\text { (DOS) }\end{array}$ & $0.03(\mathrm{n}=8)$ & $0.42(8)$ & $0.40(13)$ & $0.75(12)$ & $0.66(13)$ \\
\hline $\mathrm{Fe} / \mathrm{Al}$ & $0.57(4)$ & $0.55(4)$ & $0.56(6)$ & $1.00(5)$ & $0.70(2)$ \\
\hline $\begin{array}{c}\mathrm{Mo} / \mathrm{Al} \\
(\mathrm{ppm} / \mathrm{wt} . \%)\end{array}$ & $0.29(1)$ & $0.48(4)$ & $0.45(6)$ & $19.20(5)$ & $13.52(2)$ \\
\hline
\end{tabular}

Average shale (continental) values (Taylor and McLennan, 1985)

$\mathrm{Fe} / \mathrm{Al}=\sim 0.5 ; \mathrm{Mo} / \mathrm{Al}(\mathrm{ppm} / \mathrm{wt} . \%)=\sim 10^{-1}$

Data from Lyons (unpublished data), Lyons and Berner (1992), Lyons et al. (1993), Lyons (1997).

this scavenging occurs within the sediments versus the sulfidic water column is less clear. It is clear, however, that the position of the redox interface exerts a strong control on the magnitude of enrichment occurring specifically within sulfidic pore waters, with euxinic settings yielding characteristically high but variable Mo concentrations. This variability generally tracks the amount, type, and likely, the extent of sulfurization of the organic matter, as well as the availability of dissolved Mo (Helz et al., 1996; Lyons et al., 2003; Algeo, 2004; Tribovillard et al., 2004). As for Fe, however, the sediments at Stations 5 and 15 show little to no Mo enrichment relative to the oxic-shelf and continental end member
(Table 2)—despite high levels of pore water $\mathrm{H}_{2} \mathrm{~S}$. The most reasonable interpretation for the lack of Mo enrichment is high clastic dilution in combination with rapid burial under conditions of high sedimentation. By contrast, Fe/Al and $\mathrm{Mo} / \mathrm{Al}$ ratios are elevated in Unit 1 because of scavenging under conditions of comparatively slow siliciclastic accumulation and higher $\mathrm{C}_{\text {org }}$ concentration.

\section{RADIOCARBON AND OTHER CHRONOLOGICAL CONSTRAINTS}

Chronological details for the euxinic sediments of the Black Sea have been discussed and debated for more than 30 years. Recently, the sediments at Station 
Table $3 .{ }^{14} \mathrm{C}$ results for bulk organic and inorganic carbon in ${ }^{14} \mathrm{C}$ years before present.

\begin{tabular}{|c|c|}
\hline $\begin{array}{c}\text { depth } \\
\text { interval }(\mathrm{cm})\end{array}$ & $\begin{array}{c}\text { age } \\
\left({ }^{14} \mathrm{C} \text { yBP }\right)\end{array}$ \\
\hline \multicolumn{2}{|c|}{ Station 17} \\
total organic carbon
\end{tabular}

(1) $\delta^{13} \mathrm{C}$ values were assumed to be $-20 \%$ and $0 \%$, for total organic and inorganic $C$, respectively (see Stuiver and Polach, 1977).

(2) The quoted age is in radiocarbon years using the Libby half life of 5568 years and following the conventions of Stuiver and Polach (1977). (3) Sample preparation backgrounds were subtracted based on measurements of ${ }^{14} \mathrm{C}$-free coal (for total organic $\mathrm{C}$ ) and ${ }^{14} \mathrm{C}$-free calcite (for total inorganic $\mathrm{C}$ ). Backgrounds were scaled relative to sample size.
15 have factored into this discussion, particularly as related to $\mathrm{C}_{\text {org }}$ accumulation. The Black Sea is commonly used as a natural laboratory for exploring the role of water-column anoxia in facilitating enhanced preservation of organic matter. Calvert et al. (1991) concluded that the Black Sea is not a site of anomalous $\mathrm{C}_{\text {org }}$ accumulation when compared to oxic sites of similar water depth, sedimentation rate, and primary production (also Arthur et al., 1994). This conclusion ultimately hinges on $\mathrm{C}_{\text {org }}$ accumulation rates obtained from radiocarbon ages for the total organic carbon pool of recent Black Sea sediments. Calvert et al. (1991) dated sediments by accelerator mass spectrometry (AMS) at stations 9, 14, and 15 of Leg 4 of the $1988 \mathrm{R} / \mathrm{V}$ Knorr expedition (Figure 1; see Lyons [1991] for station descriptions), yielding sedimentation rates of $15.9,15.8$, and $17.0 \mathrm{~cm} / \mathrm{ky}$, respectively. Sediments at Stations 9 and 14 consist of classic microlaminated, coccolith-rich Unit 1 sediment (Lyons and Berner, 1992).

Debates over the chronological details of Unit 1 have included historical discrepancies between varve-count and radiocarbon age determinations. However, recent estimates for sedimentation rates based on radiocarbon, ${ }^{210} \mathrm{~Pb}$, and varve counts have converged on an estimate of ca. 15 to $20 \mathrm{~cm} / \mathrm{ky}$ (Calvert et al., 1991; Crusius and Anderson, 1992; Arthur et al., 1994; Jones and Gagnon, 1994; Arthur and Dean, 1998).

Although the different dating methods are now showing reasonable agreement for Unit 1, the $17.0 \mathrm{~cm} / \mathrm{ky}$ estimate of Calvert et al. (1991) for our Station 15 remains a mystery. This rate is in direct conflict with the downcore persistence of ${ }^{137} \mathrm{Cs}$ (an anthropogenic radionuclide linked to atmospheric testing of thermonuclear devices in the 1950s and 1960s) to depths in excess of $30 \mathrm{~cm}$ at Station 15 and $\mathrm{a}^{210} \mathrm{~Pb}$ sedimentation rate of 0.77 $\mathrm{cm} / \mathrm{y}$ reported by Anderson et al. (1994). This ${ }^{210} \mathrm{~Pb}$-based sedimentation rate is also consistent with the data of Moore and O'Neill (1991) from the same station. The sediment properties, particularly the soupy fabric and persistently high AVS concentrations at depth (Figure 4), are strongly suggestive of rapid deposition. Similarly, a ${ }^{210} \mathrm{~Pb}$ sedimentation rate of $0.67 \mathrm{~cm} / \mathrm{y}$ was determined for Station 5 (R. Anderson, LamontDoherty Earth Observatory, unpublished data), and the persistence of undisturbed microlaminae suggests that physical downcore mixing of ${ }^{210} \mathrm{~Pb}$ is not a factor at either station. Other than the similarities in AMS ${ }^{14} \mathrm{C}$ profiles suggested by Calvert et al. (1991) for the deep and basinmargin anoxic sites, the sediments from the margin differ from those at Stations 9 and 14 in almost every geochemical and sedimentological parameter (Lyons, 1991, 1997; Lyons and Berner, 1992; Anderson et al., 1994).

In an effort to explore any inconsistencies in the AMS ${ }^{14} \mathrm{C}$ data of Calvert et al. (1991) in light of our full range of other sediment measurements, we have also generated detailed AMS radiocarbon profiles for total organic and total inorganic $\left(\mathrm{CaCO}_{3}\right)$ carbon at Station 15 (Table 3; Figure 6). Unlike the profile of Calvert et al. (1991) for total organic C, the bulk ${ }^{14} \mathrm{C}$ ages for the two carbon reservoirs fail to show a steady increase with depth, instead displaying highly variable trends that closely parallel each other but differ significantly in absolute values. Additionally, our ${ }^{14} \mathrm{C}$ profiles mimic sulfur geochemical evidence for nonsteady- 
state diagenesis.

In more specific terms, the bulk organic and inorganic ${ }^{14} \mathrm{C}$ ages range from approximately 500 to 2500 and 6500 and $11000{ }^{14} \mathrm{C}$ years before present (yBP), respectively, over the depth interval characterized by a persistence of elevated AVS and anthropogenic ${ }^{137} \mathrm{Cs}$ and a ${ }^{210} \mathrm{~Pb}-$ based sedimentation rate of $\mathrm{ca} .0 .8 \mathrm{~cm} / \mathrm{y}$. These ${ }^{14} \mathrm{C}$ ages are not reservoir corrected for the apparent radiocarbon age of the surface water. However, the extreme ages at Station 15, particularly for inorganic $\mathrm{C}$, and the large offset between coexisting ${ }^{14} \mathrm{C}_{\text {org }}$ and $\mathrm{Ca}^{14} \mathrm{CO}_{3}$ data, suggest that the apparent ${ }^{14} \mathrm{C}$ age of the surface water is only a secondary factor in our interpretation of the data in Figure 6 (Calvert et al., 1991; Jones and Gagnon, 1994). Collectively, these observations are consistent with a time-varying balance between inputs from primary production and those reflecting the reworking of older terrestrial and/or marine calcium carbonate and organic matter. Similarities in the trends for the organic and inorganic radiocarbon data suggest coupled reworking_-perhaps linked to regional climatic controls_-but the substantial age offsets between the two data sets argue for differences in source regions, whether marine, nonmarine, or both.

Although the trend in Figure 6 for the ${ }^{14} \mathrm{C}$ age of the organic fraction is less systematic than that of Calvert et al. (1991), the two are consistent in their age ranges between roughly 500 and $3000{ }^{14} \mathrm{C}$ yBP. From this similarity, two fundamental questions arise: (1) which trend is likely to be more correct, given that both data sets were generated from the same box core, and (2) why do the ${ }^{14} \mathrm{C}$ data generally agree with those of the deep basin, despite sedimentation rates that might actually differ by almost a factor of 50 ? The answer to the latter question is not simple, and any consistency among the deep and shallower radiocarbon data may be fortuitous. It is also possible that the deep-water organic fraction is strongly impacted by reworked, old carbon. However, the general agreement among the ${ }^{14} \mathrm{C},{ }^{210} \mathrm{~Pb}$, and varve count estimates for Unit 1 accumulation suggests that fluxes of old carbon into the deep basin must be more constant over time compared to the basin margin and may be recorded to some extent in the surface ages of 500 to $1000{ }^{14} \mathrm{C}$ yBP and the limited reactivity of the subsurface organic phases at Stations 9 and 14 (compare Calvert et al., 1991; Jones and Gagnon, 1994). Regardless, the profiles in the deep basin are dominated by ${ }^{14} \mathrm{C}$ decay, while Station 15 reflects variable inputs of old carbon under conditions of rapid accumulation.

In defense of our data and interpretations, the irregular, nonsteady-state ${ }^{14} \mathrm{C}$ trends shown in Figure 6 covary with other geochemical properties of the Station 15 muds. Recall that the DOS data

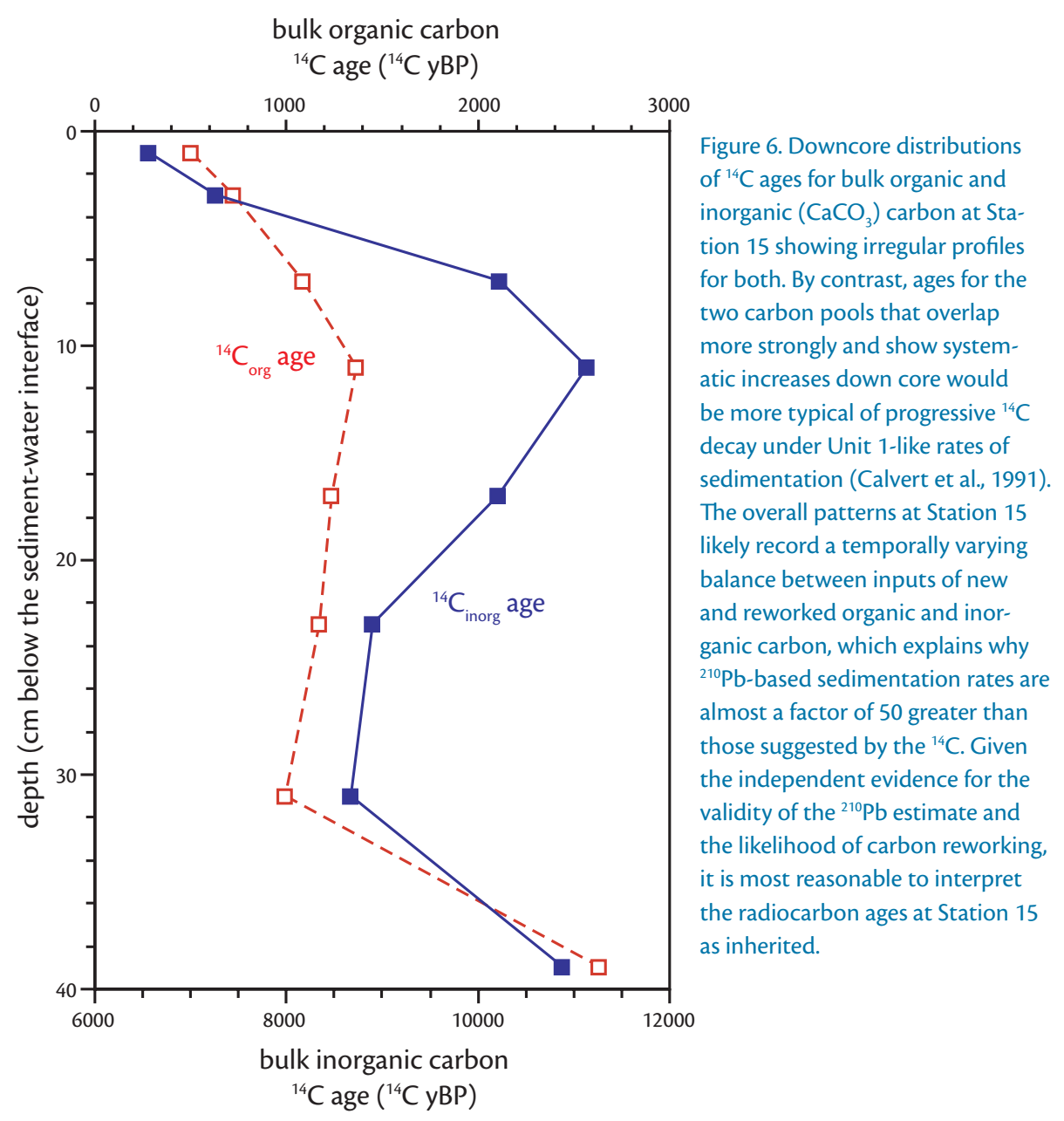




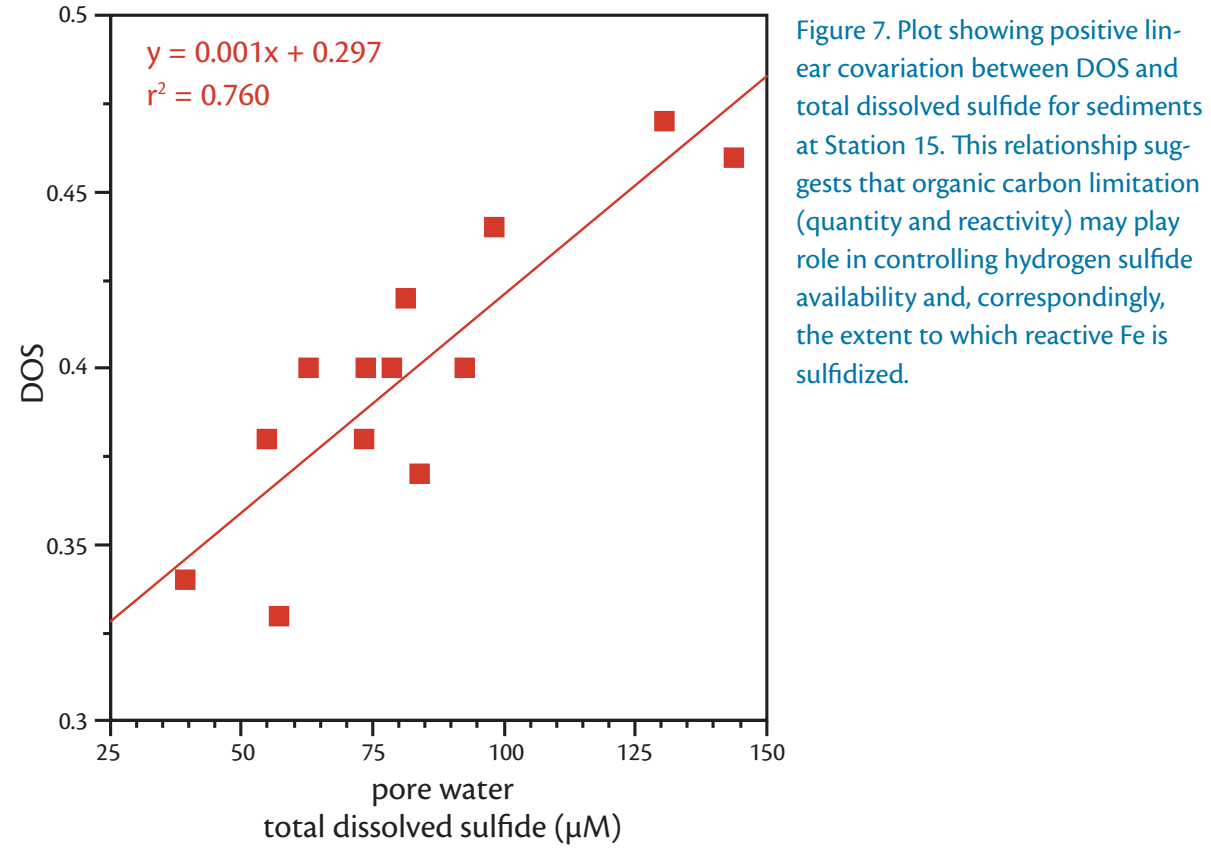

(Figure 5) show intermediate values ranging from 0.3 to 0.5 , with a nonsystematic decrease down core. Decreasing DOS with increasing depth is contrary to typical steady-state behavior, where DOS, by contrast, increases with progressive Fe sulfidation or remains roughly constant if Fe is limiting. The profile for dissolved sulfide shows similar downcore irregularity (Figure 3). Both dissolved sulfide and DOS show general positive covariation with wt. $\% \mathrm{C}_{\text {org }}$; consequently, DOS and sulfide covary positively with an $r^{2}$ value of 0.76 (Figure 7). Such relationships suggest $\mathrm{C}_{\text {org }}$ limitation in the degree of Fe sulfidation.

Beyond the relationships to $\mathrm{C}_{\text {org }}$ content, dissolved sulfide concentration and DOS vary inversely with the ${ }^{14} \mathrm{C}$ age of the bulk $\mathrm{C}_{\text {org }}$ pool. One reasonable interpretation of this negative correlation is that rates of bacterial sulfide pro- duction and the resulting degrees of $\mathrm{Fe}$ sulfidation are also linked to the overall reactivity of the bulk organic fraction as expressed in its age. More specifically, the reactivity of the bulk $\mathrm{C}_{\text {org }}$ reservoir may have varied temporally with the relative fluxes of fresh, labile marine organic matter and reworked, older, and likely more refractory organic phases. The inverse relationships between DOS and dissolved sulfide content versus ${ }^{14} \mathrm{C}$ age of bulk $\mathrm{C}_{\text {org }}$ yield $\mathrm{r}^{2}$ values of 0.58 and 0.62 , respectively, for simple linear fits of the data. Interestingly, the linear inverse relationships are even stronger relative to the ${ }^{14} \mathrm{C}$ age of bulk inorganic carbon-yielding $\mathrm{r}^{2}$ values of 0.93 and 0.80 for DOS (Figure 8) and dissolved sulfide, respectively. Although the concentration and reactivity of the organic matter are the ultimate controls on the sulfide generating potential, the ${ }^{14} \mathrm{C}$ age of inorganic $\mathrm{C}$ reservoir might be a better proxy for the original fraction of reworked material present-both organic and inorganic. Simply put, the initial ${ }^{14} \mathrm{C}$ age of the combined primary and reworked organic reservoir would be overprinted by selective remineralization of the more labile phases, which commonly results in an artificial age increase in the bulk $\mathrm{C}_{\text {org }}$ reservoir. Such selective organic remineralization may explain the inverse relationship between $\mathrm{C}_{\text {org }}$ content and its ${ }^{14} \mathrm{C}$ age seen in the top $10 \mathrm{~cm}$ of Figure 2 , although the decreasing DOS over this interval (Figure 5) suggests a more dominant control by time-varying $\mathrm{C}_{\text {org }}$ inputs and nonsteady-state diagenesis.

The present argument for substantial inputs of reworked organic and inorganic carbon at Station 15 is supported by the ${ }^{14} \mathrm{C}$ ages of bulk $\mathrm{C}_{\text {org }}$ in surficial sediments at nearby oxic Station 17 (Table 3; Figure 1). Station 17 details are available in Lyons (1991) and Lyons et al. (1993). Still to be sorted out, however, is the relationship between (1) our hypothesized $\mathrm{C}_{\text {org }}$ reworking and the resulting mixed carbon pools and (2) the work of Cowie and Hedges (1991), which argues for a dominantly marine organic reservoir at Station 15 with a common planktonic source at this station and the proximal oxic and transitional sites. Nevertheless, the present findings highlight the risks inherent in any bulk radiocarbon determination of sediment accumulation rates and point to the need for future organic geochemistry and, even more so, radiocarbon analyses that are performed at the compound-specific level (Eglinton et al., 1997). Our data also nicely illustrate the linkage between reactivity of the bulk $\mathrm{C}_{\text {org }}$ reservoir and the relative inputs of fresh and recycled organic matter. 


\section{SYNTHESIS AND IMPLICATIONS} FOR INTERPRETING THE GEOLOGIC RECORD

The black muds of the anoxic Black Sea margin are unique in their physical and chemical properties. The collective data overwhelmingly suggest high rates of deposition, implying heavy detrital sediment loading in the upper slope region. These rapid rates may be linked to sediment bypass across the adjacent shelf. Sediment accumulation rates on the shelf are less straightforwardly determined by radionuclide methods-due to heavy bioturbational overprints-but appear to be at least an order of magnitude slower (Anderson et al., 1994). However, the ${ }^{14} \mathrm{C}$ data confirm the role of local and/or more-distal reworking in the deposition at both the oxic and anoxic sites. Reworking is not inconsistent with rapid and perhaps episodic rates of sedimentation. Also, upper-slope, anoxically deposited muds of the type described here are almost certainly an important source of the uniform, muddy turbidites that are common throughout the deep basin (Lyons, 1991, 1997; Lyons and Berner, 1992).

Overall, these euxinic sediments are not a particularly representative ana$\log$ for the "typical" black shales that abound in the geologic record (Werne et al., 2002; Sageman et al., 2003), despite frequent similarities in inferred water depths of only 100 to $200 \mathrm{~m}$ for the shales. In the Black Sea, these depths characterize the basin margin, while analogous depths often occur far offshore in epicontinental settings. Ambient redox conditions and $\mathrm{C}_{\text {org }}$ richness generally dominate the properties of shales deposited within distal settings, where sediment starvation and condensation often prevail. By contrast, the high rates of accumulation on the anoxic Black Sea margin determine many of the physical and chemical characteristics of the sediments. For example, clastic dilution results in $\mathrm{C}_{\text {org }}$ concentrations that are $\sim 2.5$ times lower than those for Unit 1 in the central basin, yet $\mathrm{C}_{\text {org }}$ accumulation rates are a factor of $\sim 17$ greater on the anoxic margin (Sageman and Lyons, 2004). The sulfur isotope data on the margin are less depleted in ${ }^{34} \mathrm{~S}$ and more variable compared to those for Unit 1 (Calvert et al., 1996; Lyons, 1997; Wilkin and Arthur,
2001), reflecting stronger contributions from diagenetic iron sulfide formation on the basin margin; the iron sulfide concentrations are on the low end of values typical for black shales. Unit 1, even with its high $\mathrm{CaCO}_{3}$ content, has $\mathrm{C}_{\text {org }}$ and $S$ properties more representative of average black shale.

Despite euxinic conditions and sulfidic pore waters at euxinic margin sites, $\mathrm{Fe}$ and Mo occur at near crustal levels, equivalent to those observed on the oxic shelf as a product of continental weathering. Under such high rates of sedimen-

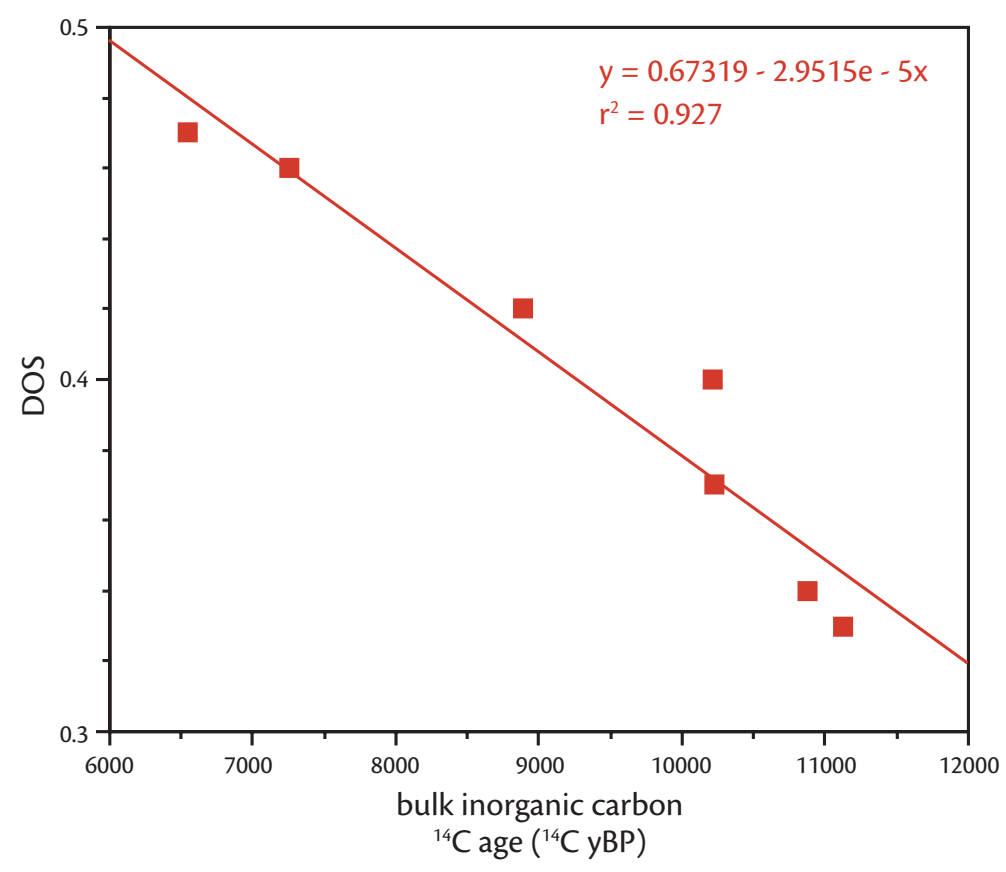

Figure 8. Plot showing inverse linear correlation between DOS and ${ }^{14} \mathrm{C}$ age of the bulk inorganic carbon reservoir at Station 15. The strong inverse relationship confirms that organic reactivity and the associated levels of hydrogen sulfide production and iron sulfidation are coupled to the extent of carbon reworking and, more specifically, to the relative fluxes of new and old organic matter. This temporally varying balance between new, reactive organic matter and old, reworked refractory material is most faithfully preserved in the ${ }^{14} \mathrm{C}$ age of the bulk inorganic $\mathrm{C}$ reservoir, which can be thought of as a proxy for the organic matter with less susceptibility to diagenetic overprinting. 
tation, syngenetic and diagenetic enrichments are swamped by detritially delivered Fe and Mo. Conversely, Unit 1 and most well studied ancient euxinic shales show appreciable enrichments in Fe and Mo. This siliciclastic swamping on the modern Black Sea margin also results in only intermediate degrees of sulfidation, not unlike those expected in sulfidic sediments beneath oxic water columns. Within this intermediate range, DOS values appear to vary as a function of the amount and reactivity of the organic matter available. The reactivity of the organic matter is reflected in the bulk, non-depositional radiocarbon ages of the organic and inorganic carbon reservoirs, which varied over time in concert with the relative fluxes of fresh, labile marine organic matter and reworked, older refractory phases. Intermediate DOS (DOP) values are not the norm for euxinic shales (Raiswell et al., 1988; Shen et al., 2003).

The high concentrations of iron monosulfide phases (AVS) in the sediments are a product of the rapid deposition and burial (Hurtgen et al., 1999). These metastable phases impart the black and dark gray colors of the basin margin sediments. The protracted diagenetic transformation to pyrite ultimately reflects rapid removal from the redox interface, where intermediate forms of sulfur (e.g., polysulfides) facilitate rapid transformation. By contrast, more-typical euxinic settings are often dominated by rapid formation and transformation of AVS in the water column (Calvert et al., 1996; Lyons, 1997; Wilkin et al., 1997, Lyons et al., 2003).

One could argue that the persistent microlamination is the only sediment property that points unambiguously to euxinic deposition in the black muds of the Black Sea margin. This attribute would express itself clearly in the ancient shale equivalent, but the high initial porosities, high AVS contents, the radionuclide data for rapid accumulation, and the ${ }^{14} \mathrm{C}$ evidence for complex mixing in the organic reservoir would all be lost. As such, the geochemical properties that are now widely used to delineate euxinia-such as high Mo content, distinctly light and uniform $\delta^{34} S$ values, high DOP, and even high $\mathrm{C}_{\text {org }}$ and $\mathrm{S}$ contents (Sageman and Lyons, 2004) —all fail as proxies for euxinia on the Black Sea margin. While these properties may be a source for concern for some workers, others will view their differences as an opportunity. For example, if the benthic ecology of an ancient black shale can be taken as definitive or even tentative independent evidence for euxinia, the atypical geochemical parameters described here can be used to delineate gradients in sedimentation or extents of organic reworking (Werne et al., 2002). The latter may also express itself in organic biomarker data that preserve deep into the geologic record. At the very least, these data illuminate and confirm some of the mechanistic underpinnings behind widely used paleoredox proxies and, in a cautionary way, point to a type of euxinic facies that may or may not be rare in the geologic record but that deviates far from the prevailing paradigm.

\section{ACKNOWLEDGMENTS}

Financial support for this work was provided the U.S. National Science Foundation, Division of Ocean Sciences. Sample collection was possible thanks to the many efforts of the crew and shipboard scientists of Leg 4 of the 1988 R/V Knorr
Black Sea expedition. We are grateful to Jim Murray and Erol Izdar for organizing the 1988 expedition and to Jim for putting together this special issue. Special thanks go to Bob Anderson for his interest in this project, his work as a Co-Chief Scientist of Leg 4, and his generously shared data. AMS radiocarbon analyses were performed under the auspices of the U.S. Department of Energy by University of California Lawrence Livermore National Laboratory under contract No. W-7405-Eng-48. We thank Ellen Kappel for her editorial guidance. 四

\section{REFERENCES}

Albert, D.B., C.D. Taylor, and C.S. Martens. 1995. Sulfate reduction rates and low molecular weight fatty acid concentrations in the water column and surficial sediments of the Black Sea. Deep-Sea Research 42:1239-1260.

Algeo, T.J. 2004. Can marine anoxic events draw down the trace-element inventory of seawater? Geology 32:1057-1060.

Anderson, R.F., T.W. Lyons, and G.L Cowie. 1994. Sedimentary record of a shoaling of the oxic/ anoxic interface in the Black Sea. Marine Geology 116:373-384.

Anderson, T.F. and R. Raiswell. 2004. Sources and mechanisms for the enrichment of highly reactive iron in euxinic Black Sea sediments. American Journal of Science 304:203-233.

Arnold, G.L., A.D. Anbar, J. Barling, and T.W. Lyons. 2004. Molybdenum isotope evidence for widespread anoxia in mid-Proterozoic oceans. Science 304:87-90.

Arthur, M.A. and W.E. Dean. 1998. Organic-matter production and preservation and evolution of anoxia in the Holocene Black Sea. Paleoceanography 13:395-411.

Arthur, M.A., W.E. Dean, E.D. Neff, B.J. Hay, J. King, and G. Jones. 1994. Varve calibrated records of carbonate and organic carbon accumulation over the last 2000 years in the Black Sea. Global Biogeochemical Cycles 8:195-217.

Calvert, S.E., R.E. Karlin, L.J. Toolin, D.J. Donahue, J.R. Southon, and J.S. Vogel. 1991. Low organic carbon accumulation rates in Black Sea sediments. Nature 350:692-695.

Calvert, S.E., H.D. Thode, D. Yeung, and R.E. Karlin. 1996. A stable isotope study of pyrite formation in the Late Pleistocene and Holocene sediments of the Black Sea. Geochimica et Cosmochimica Acta 60:1261-1270. 
Canfield, D.E., T.W. Lyons, and R. Raiswell. 1996. A model for iron deposition to euxinic Black Sea sediments. American Journal of Science 296:818834.

Cowie, G.L. and J.I. Hedges. 1991. Organic carbon and nitrogen geochemistry of Black Sea surface sediments from stations spanning the oxic:anoxic boundary. Pp. 343-359 in Black Sea Oceanography, J.W. Murray and E. Izdar, eds. NATO Advanced Studies Institute Series. Kluwer, Dordrecht, The Netherlands.

Crusius, J. and R.F. Anderson. 1992. Inconsistencies in accumulation rates of Black Sea sediments inferred from records of laminae and ${ }^{210} \mathrm{~Pb}$. Paleoceanography 7:215-227.

Eglinton, T.I., B.C. Benitez-Nelson, A. Pearson. A.P. McNichol, J.E. Bauer, and E.R.M. Druffel. 1997. Variability in radiocarbon ages of individual organic compounds from marine sediments. Science 277:796-799.

Helz, G.R., C.V. Miller, J.M. Charnock, J.F.W. Mosselmans, R.A.D. Pattrick, C.D. Garner, and D.J. Vaughan. 1996. Mechanisms of molybdenum removal from the sea and its concentration in black shales: EXAFS evidence. Geochimica et Cosmochimica Acta 60:3631-3642.

Hurtgen, M.T., T.W. Lyons, E.D. Ingall, and A.M. Cruse. 1999. Anomalous enrichments of iron monosulfide in euxinic marine sediments and the role of $\mathrm{H}_{2} \mathrm{~S}$ in iron sulfide transformations: Examples from Effingham Inlet, Orca Basin, and the Black Sea. American Journal of Science 299:556-588.

Jones, G.A. and A.R. Gagnon. 1994. Radiocarbon chronology of Black Sea sediments. Deep-Sea Research 41:531-557.

Jørgensen, B.B., A. Weber, and J. Zopfi. 2001. Sulfate reduction and anaerobic methane oxidation in Black Sea sediments. Deep-Sea Research 48:2097-2120.

Lyons, T.W. 1991. Upper Holocene sediments of the Black Sea: summary of Leg 4 box cores (1988 Black Sea Oceanographic Expedition). Pp. 401-441 in Black Sea Oceanography, J.W. Murray and E. Izdar, eds. NATO Advanced Studies Institute Series. Kluwer, Dordrecht, The Netherlands.

Lyons, T.W. 1997. Sulfur isotopic trends and pathways of iron sulfide formation in upper Holocene sediments of the anoxic Black Sea. Geochimica et Cosmochimica Acta 61:3367-3382.

Lyons, T.W. and R.A. Berner. 1992. Carbon-sulfuriron systematics of the uppermost deep-water sediments of the Black Sea. Chemical Geology 99:1-27.

Lyons, T.W., R.A. Berner, and R.F. Anderson. 1993. Evidence for large pre-industrial perturbations of the Black Sea chemocline. Nature 365:538540 .
Lyons, T.W., J.P. Werne, D.J. Hollander, and R.W. Murray. 2003. Contrasting sulfur geochemistry and $\mathrm{Fe} / \mathrm{Al}$ and $\mathrm{Mo} / \mathrm{Al}$ ratios across the last oxicto-anoxic transition in the Cariaco Basin, Venezuela. Chemical Geology 195:131-157.

Moore, W.S. and D.J. O’Neill. 1991. Radionuclide distributions in recent Black Sea sediments. Pp. 343-359 in Black Sea Oceanography, J.W. Murray and E. Izdar, eds. NATO Advanced Studies Institute Series. Kluwer, Dordrecht, The Netherlands.

Murray J.W., H.W. Jannasch, S. Honjo, R.F. Anderson, W.S. Reeburgh, Z. Top, G.E. Friederich, L.A. Codispoti, and E. Izdar. 1989. Unexpected changes in the oxic/anoxic interface in the Black Sea. Nature 338:411-413.

Raiswell, R., and D.E. Canfield. 1998. Sources of iron for pyrite formation in marine sediments. American Journal of Science 298:219-245.

Raiswell, R., F. Buckley, R.A. Berner, and T.F. Anderson. 1988. Degree of pyritization of iron as a paleoenvironmental indicator of bottom-water oxygenation. Journal of Sedimentary Petrology 58:812-819.

Rickard, D. and G.W. Luther, III. 1997. Kinetics of pyrite formation by the $\mathrm{H}_{2} \mathrm{~S}$ oxidation of iron(II) monosulfide in aqueous solutions between 25 and $125^{\circ} \mathrm{C}$ : The mechanism. Geochimica et Cosmochimica Acta 61:135-147.

Ross, D.A., E.T. Degens, and J. MacIlvaine. 1970. Black Sea: Recent sedimentary history. Science 170:163-165.

Sageman, B.B. and T.W. Lyons. 2004. Geochemistry of fine-grained sediments and sedimentary rocks. Pp. 115-158 in Sediments, Diagenesis, and Sedimentary Rocks, F.T. Mackenzie, ed. Treatise on Geochemistry 7. Elsevier, BV., Amsterdam, The Netherlands.

Sageman, B.B., A.E. Murphy, J.P. Werne, C.E. Ver Straeten, D.J. Hollander, and T.W. Lyons. 2003. A tale of shales: The relative roles of production, decomposition, and dilution in the accumulation of organic-rich strata, Middle-Upper Devonian, Appalachian basin. Chemical Geology 195:229-273.

Schoonen. M.A.A. 2004. Mechanisms of sedimentary pyrite formation. Pp. 117-134 in Sulfur Biogeochemistry—Past and Present, J.P. Amend, K.J. Edwards, and T.W. Lyons, eds. Geological Society of America Special Paper 379. Geological Society of America, Boulder, CO.

Shen, Y., A.H. Knoll, and M.R. Walter. 2003. Evidence for low sulphate and anoxia in a midProterozoic marine basin. Nature 423:632-635. Sinninghe Damsté, J.S., S.G. Wakeham, M.E.L. Kohnen, J.M. Hayes, and J.W. de Leeuw. 1993. A 6,000-year sedimentary molecular record of chemocline excursions in the Black Sea. Nature 362: 827-829.
Stuvier, M. and H.A. Polach. 1977. Discussion: Reporting of ${ }^{14} \mathrm{C}$ data. 1977. Radiocarbon 19:355363.

Taylor, S.R. and S.M. McLennan. 1985. The Continental Crust: Its Composition and Evolution. Blackwell, Oxford, 312 pp.

Toth, D.J. and A. Lerman. 1977. Organic matter reactivity and sedimentation rates in the ocean. American Journal of Science 277: 465-485.

Tribovillard, N., A. Riboulleau, T. Lyons, and F. Baudin. 2004. Enhanced trapping of molybdenum by sulfurized marine organic matter of marine origin in Mesozoic limestones and shales. Chemical Geology 213:385-401.

Werne, J.P., B.B. Sageman, T.W. Lyons, and D.J. Hollander. 2002. An integrated assessment of a "type euxinic" deposit: evidence from multiple controls on black shale deposition in the Middle Devonian Oatka Creek Formation. American Journal of Science 302:110-143.

Wignall, P.B. and R. Newton. 1998. Pyrite framboid diameter as a measure of oxygen deficiency in ancient mudrocks. American Journal of Science 298:537-552.

Wijsman, J.W.M., J.J. Middelburg, P.M.J. Herman, M.E. Böttcher, and C.H.R. Heip. 2001a. Sulfur and iron speciation in surface sediments along the northwestern margin of the Black Sea. $M a$ rine Chemistry 74:261-278.

Wijsman, J.W.M., J.J. Middelburg, and C.H.R. Heip. 2001b. Reactive iron in Black Sea sediments: implications for iron cycling. Marine Geology 172:167-180.

Wilkin, R.T. and M.A. Arthur. 2001. Variations in pyrite texture, sulfur isotope composition, and iron systematics in the Black Sea: Evidence for Late Pleistocene to Holocene excursions of the $\mathrm{O}_{2}-\mathrm{H}_{2} \mathrm{~S}$ redox transition. Geochimica et Cosmochimica Acta 65:1399-1416.

Wilkin, R.T., M.A. Arthur, and W.E. Dean. 1997. History of water-column anoxia in the Black Sea indicated by pyrite framboid size distributions. Earth and Planetary Science Letters 148:517-525. 